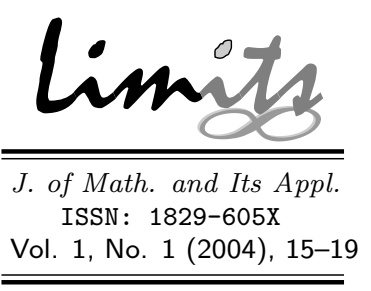

\title{
Metode Asimilasi Data sebagai Estimasi Penyelesaian Masalah-masalah Lingkungan
}

\author{
Erna Apriliani \\ Jurusan Matematika \\ Institut Teknologi Sepuluh Nopember, Surabaya
}

\begin{abstract}
Abstrak
Asimilasi Data merupakan metode estimasi sistem dinamik stokastik yang merupakan penggabungan model dinamik dengan data-data pengukuran. Metode Asimilasi data telah banyak digunakan dalam mengestimasi masalah-masalah meteorologi, hidrodinamika. Di sini akan dibahas tentang apa metode asimilasi data itu, bilamana dipergunakan, apa kelebihannya dibandingkan dengan metode lainnya serta bagaimana penerapannya pada masalah lingkungan
\end{abstract}

Kata kunci: sistem dinamik stokastik, interpolasi optimum, filter Kalman

\section{Pendahuluan}

Dalam kehidupan sehari-hari seringkali kita dihadapkan pada masalah - masalah estimasi atau prediksi, khususnya untuk masalah yang bergantung pada waktu/masalah dinamik. Untuk sistem dinamik deterministik, yaitu tidak memuat faktor stokastik maka penyelesaian secara numerik dari sistem dinamik tersebut dapat membantu menyelesaikannya. Sedangkan untuk sistem dinamik stokastik biasanya data-data pengukuran banyak dipergunakan untuk memodelkan serta memprediksi sistem tersebut untuk waktu yang akan datang.

Pemodelan dan estimasi berdasarkan datadata pengukuran belum tentu mencerminkan sistem yang sebenarnya, karena keterbatasan data yang dapat diperoleh. Pada pemodelan dan estimasi berdasarkan sistem dinamik yang ada terjadi penumpukan error estimasi yang terjadi karena kesalahan estimasi pada tiap langkah waktu. Untuk mengantisipasi kekurangan dan kelebihan masing-masing metode digunakan metode asimilasi data. Metode asi- milasi data merupakan penggabungan penyelesaian sistem dinamik dan data-data pengukuran untuk memperbaiki hasil estimasi sehingga penumpukan error dapat dikurangi.

Masalah-masalah lingkungan seperti penyebaran limbah cair dilaut, penyebaran limbah cair pada air tanah, pencemaran udara, distribusi suhu udara pada suatu daerah merupakan sistem dinamik yang tidak terlepas dari pengaruh faktor stokastik. Oleh karena itu perlu dikaji penerapan metode asimilasi data untuk menyelesaikan masalah-masalah tersebut, khususnya masalah limbah cair di laut. Metode asimilasi data yang dipergunakan disini adalah filter Kalman, sedangkan pemakaian kedua metode lainnya masih dalam kajian.

\section{Metode Asimilasi Data}

Metode asimilasi data pada awalnya dikembangkan untuk memprediksi cuaca dan telah banyak diterapkan dalam masalah meteorologi [12], [11]. Kemudian penerapan metode asi- 
milasi data pada masalah-masalah yang lainnya telah banyak dilakukan antara lain oleh Zhang, 1996 [12] untuk pemodelan polusi udara, Voorrips, 1998 [11] menerapkan pada model gelombang laut, dan pada tahun 1999, Miller [8] menuliskan metode asimilasi data untuk model-model stokastik tak linear.

Langkah sederhana dari asimilasi data adalah mengganti atau memperbaiki model yang sudah ada berdasarkan data pengukuran yang diperoleh (substitusi data). Tetapi substitusi data tidak selalu dapat dilakukan karena substitusi data tidak dibenarkan dalam hukumhukum fisika akibatnya model menjadi tidak setimbang dan hasil simulasi yang diperoleh tidak bermanfaat lagi [12]. Oleh karena itu yang paling penting dalam masalah asimilasi data adalah bagaimana mengkombinasikan antara model dan data pengukuran sehingga diperoleh hasil estimasi yang terbaik.

Sampai saat ini ada tiga teknik yang dapat dipergunakan dalam metode asimilasi data yaitu:

- Interpolasi Optimum

- Filter Kalman

- Metode Variasional 4-D

\subsection{Interpolasi Optimum}

Metode Interpolasi Optimum merupakan metode yang paling sering dipergunakan untuk memprediksi cuaca atau masalah meteorologi. Metode ini merupakan metode asimilasi data dengan pendekatan statistik yaitu teknik akar kuadrat terkecil (least squares technique). Metode ini dikembangkan oleh Lev Gandin (1963). Misalkan diberikan sistem dinamik

$$
x_{k}=f_{k}\left(x_{k-1}, u_{k-1}\right)
$$

dengan pengukuran

$$
z_{k}=H_{k} x_{k}
$$

maka algoritma Interpolasi Optimum [11] adalah

(i) variabel keadaan $x_{k}$ diprediksi berdasarkan

$$
x_{k}^{f}=E\left(x_{k}\right)=\overline{x_{k}}
$$

dengan kovariansi kesalahan estimasi

$$
p_{k}^{f}=E\left(\left(x_{k}-\overline{x_{k}}\right)\left(x_{k}-\overline{x_{k}}\right)^{t}\right)
$$

dimana $E($.$) adalah nilai ekspektasi.$ (ii) Bobot koreksi kesalahan estimasi

$$
K_{k}=P_{k}^{f} H_{k}^{t}\left[H_{k} P_{k}^{f} H_{k}^{t}+R_{k}\right]^{(-1)}
$$

(iii) Estimasi optimum dari variabel keadaan setelah data pengukuran dimasukkan

$$
x_{k}=x_{k}^{f}+K_{k}\left(z_{k}-H_{k} x_{k}^{f}\right)
$$

dengan $R_{k}$ kovariansi kesalahan pengukuran.

\subsection{Filter Kalman}

Filter Kalman merupakan perumuman dari interpolasi optimum. Perbedaan antara Filter Kalman dan Interpolasi Optimum antara lain [9]:

- memasukkan model prediksi linear yang tidak tampak pada interpolasi optimum

- kovariansi kesalahan prediksi diperbarui setiap satuan waktu

- diterapkan secara global yaitu semua data pengamatan/pengukuran digunakan untuk mengestimasi semua variabel secara simultas, sedangkan interpolasi optimum hanya menganalisa setiap titik/variabel yang dipilih disekitar pengamatan/pengukuran.

Misalkan diberikan sistem dinamik stokastik

$$
x_{k+1}=A_{k} x_{k}+B_{k} u_{k}+G_{k} w_{k}
$$

dengan pengukuran

$$
z_{k+1}=H_{k+1} x_{k+1}+v_{k}
$$

Untuk sistem dinamik stokastik (7),(8) tidak dapat dilakukan estimasi variabel keadaan $x_{k}$ dengan cara sistem observer biasa karena kesalahan estimasinya $\tilde{x}_{k}$ tidak konvergen ke nol [3]. Estimasi variabel keadaan dilakukan dengan menggunakan filter Kalman.

Filter Kalman merupakan estimator linear terbaik untuk $x_{o}, w_{k}$ dan $v_{k}$ berdistribusi sebarang dan merupakan estimator optimum untuk $x_{o}, w_{k}$ dan $v_{k}$ berdistribusi normal. Pada filter Kalman estimasi variabel keadaan dilakukan dengan cara memprediksi varibel tersebut dan selanjutnya dilakukan pengukuran untuk mengkoreksi prediksi variabel secara rekursi dengan cara meminimumkan kovarian kesalahan penaksiran $\left(x_{k}-\hat{x}_{k}\right) ; x_{k}$ merupakan variabel keadaan sebenarnya dan $\hat{x}_{k}$ merupakan penaksiran dari variabel keadaan.

Secara lengkap, algoritma dari filter Kalman adalah sebagai berikut [1] 
(i) Tahap Prediksi (Time Update)

$$
\begin{aligned}
& \hat{x}_{k+1}(-)=A_{k} \hat{x}_{k}+B_{k} u_{k} \\
& P_{k+1}(-)=A_{k} P_{k} A_{k}^{t}+G_{k} Q_{k} G_{k}^{t}
\end{aligned}
$$

(ii) Tahap Koreksi (Measurement Update)

$$
\begin{aligned}
K_{k} & =P_{k}(-) H_{k}^{t}\left(H_{k} P_{k}(-) H_{k}^{t}+R_{k}\right)^{-1} \\
P_{k} & =\left(I-K_{k} H_{k}\right) P_{k}(-) \\
\hat{x}_{k} & =\hat{x}_{k}(-)+K_{k}\left(z_{k}-H_{k} \widehat{x}_{k}(-)\right)
\end{aligned}
$$

Diberikan taksiran awal $\hat{x}_{0}=x_{0}$ dengan kovarian kesalahan penaksiran awal $P_{0}(+)=$ $P_{0}>0$

\subsection{Metode Variasional 4-D}

Metode lain yang juga sering digunakan dalam metode asimilasi data adalah Metode Variasional Empat Dimensi. Ide dasar metode ini adalah meminimumkan jarak antara trayektori penyelesaian model dengan pengamatan pada interval waktu tertentu [12]. Metode yang digunakan untuk mendapatkan jarak minimal adalah metode adjoint. Pada metode ini diperlukan data untuk sepanjang interval waktu untuk memperbaiki model sehingga sangat sulit diterapkan untuk peramalan secara on-line.

\section{Asimilasi Data pada Masalah Lingkungan}

Masalah-masalah lingkungan yang dimaksudkan di sini adalah masalah-masalah yang merupakan sistem dinamik stokastik, baik timevariant maupun time-invariant, seperti ketinggian air sungai, ketinggian gelombang air laut, proses salinasi, pencemaran air tanah, pencemaran udara dan masalah lainnya. Metode asimilasi data ini telah diterapkan pada pemodelan polusi udara [12], model-model kimia di atmosfir [10], model gelombang laut [11].

Penulis beserta tim penelitiannya telah menggunakan filter Kalman sebagai metode asimilasi data pada masalah estimasi ketinggian air sungai [4], estimasi penyebaran limbah cair di laut [7], estimasi aliran air tanah [2]. Pada saat ini sedang dikaji metode asimilasi data lain untuk masalah estimasi ketinggian air tanah, estimasi penyebaran limbah cair pada air tanah dan estimasi penyebaran limbah cair di laut dengan metode variasional empat dimensi. Pengembangan algoritma pada metode asimilasi data juga dikaji dan dikembangkan misalnya modifikasi filter Kalman [5, 6].

Dalam melakukan penerapan Filter Kalman sebagai metode asimilasi data dilakukan langkah-langkah sebagai berikut:

(i) Pemodelan: Model dari masalah tersebut dibangun berdasarkan hukum-hukum fisika dan fenomena alam yang berlaku, misalnya model aliran air sungai mempunyai model matematika yang dikenal dengan persamaan Saint Venant.

$$
\begin{array}{r}
\frac{\partial h}{\partial t}+D \frac{\partial u}{\partial x}=0 \\
\frac{\partial u}{\partial t}+g \frac{\partial h}{\partial x}+C_{f} u=0
\end{array}
$$

dengan syarat batas dan syarat awal

$$
\begin{aligned}
h(0, t) & =\psi_{b}(t) \\
h(x, 0) & =1 \\
u(x, 0) & =0 \\
u(L, t) & =u_{N}(t)
\end{aligned}
$$

dimana $h(x, t)$ ketinggian air diatas $D$, $D$ kedalaman sungai, $u(x, t)$ rata-rata kecepatan aliran sepanjang irisan penampang melintang, $t$ menyatakan waktu, $x$ posisi sepanjang sungai, $g$ kecepatan gravitasi, $C_{f}$ konstanta gesekan, $\psi_{b}$ ketinggian air pada posisi $x_{o}$ dan $u(L, t)$ kecepatan air pada batas $x_{N}$.

(ii) Pendiskritan: perlu dikaji metode pendiskritan yang sesuai dengan masalah yang dikaji, misalnya untuk persamaan Saint Venant tersebut digunakan skema Pressmann. Dari pendiskritan ini diperoleh bentuk sistem ruang keadaan (state space system)

$$
X_{k+1}=A_{k} X_{k}+B_{k} U_{k}
$$

(iii) Pengukuran yang dapat dilakukan: Pada tahap ini harus dikonstruksi persamaan pengukuran yang mengkaitan datadata pengukuran yang diperoleh dengan variabel keadaan yang akan diestimasi. Perlu diperhatikan bahwa model sistem dan pengukuran haruslah terobservasi (observable).

(iv) Pembentukan Sistem Stokastik: Di sini perlu dikaji faktor-faktor stokastik 
yang mempengaruhi sistem dan merupakan noise pada sistem serta noise pada pengukuran.

$$
X_{k+1}=A_{k} X_{k}+B_{k} U_{k}+G_{k} W_{k}
$$

dengan $W_{k}$ gangguan sistem yang diasumsikan berdistribusi normal Gauss dengan mean nol dan kovarians $Q_{k}$.

Misalkan pengukuran yang diperoleh mempunyai persamaan

$$
z_{k+1}=H_{k+1} X_{k+1}+V_{k+1}
$$

dengan $V_{k}$ gangguan pengukuran yang diasumsikan berdistribusi normal Gauss dengan mean nol dan kovarians $R_{k}$.

(v) Simulasi penerapan filter Kalman: dibuat program komputer untuk mensimulasikan hasil estimasi berdasarkan data-data pengukuran.

Pada langkah-langkah tersebut di atas, faktor stokastik dapat muncul pada saat pemodelan sehingga sistemnya dinamakan sistem persamaan diferensial stokastik atau dibentuk setelah pendiskritan dan pembentukan persamaan pengukuran untuk memudahkan masalah.

Pada penelitian-penelitian yang telah dilakukan penulis dan tim, data-data pengukuran dibangkitkan dari simulasi yaitu menambahkan variabel random berdistribusi normal pada sistem deterministiknya (model dan pengukuran). Hasil estimasi dengan menggunakan filter Kalman adalah sebagai berikut:

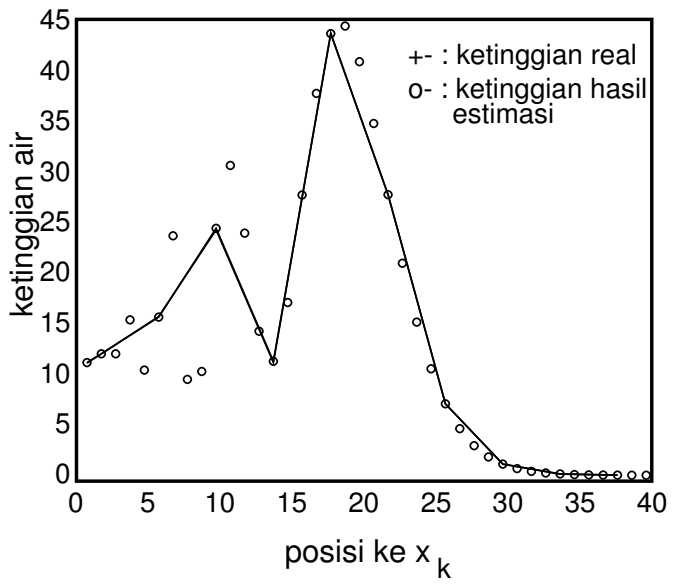

Gambar 1: Estimasi Ketinggian Air

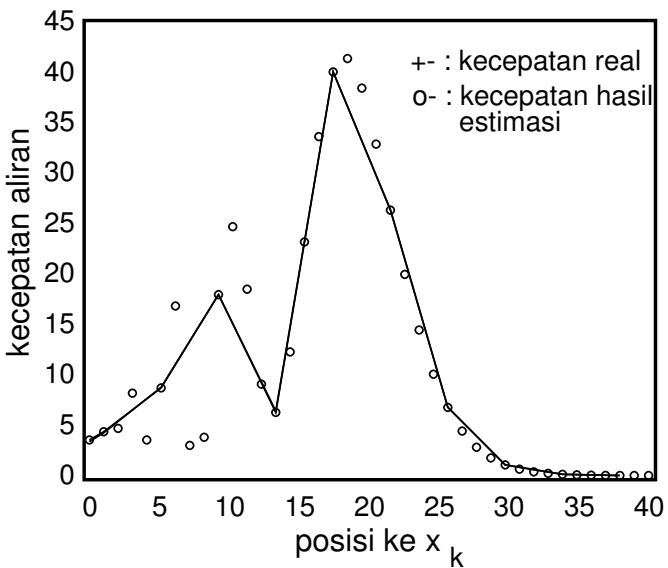

Gambar 2: Estimasi Kecepatan Aliran Air

\section{Penutup}

Berdasarkan kajian pustaka dan beberapa penelitian yang telah dilakukan dapat disimpulkan bahwa metode asimilasi data dapat diterapkan untuk mengestimasi masalah-masalah lingkungan; sedangkan efisiensi waktu komputasi dan tingkat akurasi masing-masing dari ketiga metode masih perlu dikaji. Modifikasi algoritma masih perlu dikembangkan untuk mendapatkan hasil yang lebih efisien dan akurat.

\section{Daftar Pustaka}

[1] Anderson, R., Optimal Filtering, Prentice Hall, 1979.

[2] Handayani,A., Estimasi Filter Kalman terhadap Distribusi Konsentrasi Polusi Air Tanah, Tugas Akhir S1, ITS, 2003.

[3] Apriliani, E., "Perbandingan antara Observer Deterministik dan Filter Kalman", Majalah Ilmiah Himpunan Matematika Indonesia, Vol. 6, no. 1, 2000.

[4] Apriliani, E., "The Application of the Modified RRSQRT Filter on One Dimensional Shallow Water Problem", Proceedings ITB, Vol 34 no 1, ITB, 2001.

[5] Apriliani, E., "The Reduced Rank SRIF", Majalah Ilmiah Himpunan Matematika Indonesia, vol. 7 no. 2, 2001.

[6] Apriliani, E., "The Estimation Of The Water Level By The Reduced Rank 
Square Root Information Filter", Proceedings of the Asia - Pasific Vibration Conference, vol. II, Jilin Science and Technology Press, China, 2001.

[7] Endang S., Estimasi Penyebaran Limbah Cair di Laut dengan Filter Kalman dan Modifikasi Filter RRSQR, Tugas Akhir S1, ITS, 2002.

[8] Miller, R.N., Carter, E.F. and Blue, S.T, Data Assimilation into Nonlinear Stochastic Models, Tellus 51A, 1999.
[9] Schlatter, T.W., -, Four-Dimensional Data Assimilation, internet.

[10] Seger, A., Data Assimilation in Atmospheric Chemestry Models Using Kalman Filtering, Desertation TU Delft, 2002.

[11] Voorrips,A., Sequential Data Assimilation Methods for Ocean Wave Models, Disertation, The Netherlands, 1998.

[12] Zhang, Xue-Fen, Data Assimilation in Air Pollutin Modelling, Disertation, TU Delft, 1996. 